\title{
Leaf litter decomposition in temperate deciduous forest stands with a decreasing fraction of beech (Fagus sylvatica)
}

\author{
Mascha Jacob $\cdot$ Karin Viedenz $\cdot$ Andrea Polle • \\ Frank M. Thomas
}

Received: 24 November 2008 / Accepted: 14 June 2010/Published online: 2 July 2010

(C) The Author(s) 2010. This article is published with open access at Springerlink.com

\begin{abstract}
We hypothesised that the decomposition rates of leaf litter will increase along a gradient of decreasing fraction of the European beech (Fagus sylvatica) and increasing tree species diversity in the generally beechdominated Central European temperate deciduous forests due to an increase in litter quality. We studied the decomposition of leaf litter including its lignin fraction in monospecific (pure beech) stands and in stands with up to five tree genera (Acer spp., Carpinus betulus, Fagus sylvatica, Fraxinus excelsior, Tilia spp.) using a litterbag approach. Litter and lignin decomposition was more rapid in stand-representative litter from multispecific stands than in litter from pure beech stands. Except for beech litter, the decomposition rates of species-specific tree litter did not differ significantly among the stand types, but were most rapid in Fraxinus excelsior and slowest in beech in an interspecific comparison. Pairwise comparisons of the decomposition of beech litter with litter of the other tree species (except for Acer platanoides) revealed a "home field advantage" of up to $20 \%$ (more rapid litter
\end{abstract}

Communicated by Stephan Hättenschwiler.

M. Jacob

Plant Ecology, Albrecht von Haller Institute for Plant Sciences, Georg-August-Universität Göttingen, Untere Karspüle 2,

37073 Göttingen, Germany

K. Viedenz · F. M. Thomas $(\bowtie)$

Geobotany, Faculty of Geography and Geosciences, University of Trier, Behringstr. 21, 54296 Trier, Germany

e-mail: thomasf@uni-trier.de

\section{A. Polle}

Department of Forest Botany and Tree Physiology,

Büsgen Institute, Georg-August-Universität Göttingen,

Büsgenweg 2, 37077 Göttingen, Germany decomposition in stands with a high fraction of its own species than in stands with a different tree species composition). Decomposition of stand-representative litter mixtures displayed additive characteristics, not significantly more rapid than predicted by the decomposition of litter from the individual tree species. Leaf litter decomposition rates were positively correlated with the initial $\mathrm{N}$ and $\mathrm{Ca}$ concentrations of the litter, and negatively with the initial $\mathrm{C}: \mathrm{N}, \mathrm{C}: \mathrm{P}$ and lignin:N ratios. The results support our hypothesis that the overall decomposition rates are mainly influenced by the chemical composition of the individual litter species. Thus, the fraction of individual tree species in the species composition seems to be more important for the litter decomposition rates than tree species diversity itself.

Keywords Biodiversity - Central Europe $\cdot$ Element ratio · Litter degradation $\cdot$ Litterbag

\section{Introduction}

The significance of plant species diversity for ecosystem functioning is a central issue in current ecological research (Hooper et al. 2005; Balvanera et al. 2006). To date, most studies have focused on diversity-productivity relationships in experimental grasslands or forest plantations (Scherer-Lorenzen et al. 2005; Spehn et al. 2005). In these studies, positive relationships have generally been found between primary productivity and plant species diversity (Hooper et al. 2005; Spehn et al. 2005). Less is known on biodiversity effects on other key ecosystem processes such as decomposition and nutrient cycling. The decomposition process of plant litter influences the release of essential plant nutrients such as nitrogen $(\mathrm{N})$ and, thereby, exerts a 
large influence on the growth rates of plant species (e.g., Cotrufo et al. 2000; Parton et al. 2007).

Most studies on litter decomposition in forests have included only two or three tree litter species and compared monocultures with just one mixing treatment. This narrow range of methodical approaches strongly limits the thorough assessment of diversity effects and is one reason why generalisations of litter-mass loss as a function of litter diversity are not yet possible (Hättenschwiler et al. 2005).

A substantial fraction of the studies indicates that mass loss from various litter mixtures is more rapid than would have been predicted from the decay rates of the individual species included in the mixture (Hättenschwiler and Gasser 2005; Chapman and Koch 2007; Pérez Harguindeguy et al. 2008). Thus, it exhibits non-additive characteristics, which is in contrast to additive responses that can be predicted from the decay of the individual litter species (Gartner and Cardon 2004). According to Hättenschwiler et al. (2005), these non-additive (i.e., synergistic) effects can be brought about by four complexes of mechanisms: (1) nutrient transfer: preferential decomposition of high-quality litter increases nutrient availability and induces nutrient transfer to the low-quality litter that, in turn, will be decomposed more rapidly (see also Salamanca et al. 1998); (2) stimulating effects of specific litter compounds (cf. Schimel et al. 1998, who demonstrated, however, that retarding effects are possible as well); (3) improved microclimatic conditions; or (4) interactions across trophic levels of decomposers, e.g., regulation of the population density at lower trophic levels by species at higher trophic levels, which can depend on the diversity of litter species. To date, however, no general pattern of litter-diversity effects on the mass loss from litter during decomposition has emerged (e.g., Wardle et al. 1997; 2009).

The decomposition of leaf litter is largely influenced by the concentrations and ratios of nutrients (Berg and McClaugherty 2008). In general, decomposition rates increase with a decrease in the ratio of carbon to $\mathrm{N}(\mathrm{C}: \mathrm{N}$ ratio), which is therefore an important indicator of litter quality (e.g., Heal et al. 1997). Another constituent limiting the rate of litter degradation is lignin (e.g., Melillo et al. 1982; Osono and Takeda 2005), a complex aromatic heteropolymer in cell walls, which is one of the litter components that are most recalcitrant to decomposition (Osono 2007; Berg and McClaugherty 2008). Therefore, not only the species mixture of the litter per se but also the presence or absence of individual litter species can influence the decomposition rate within a mixture.

In temperate forests, several studies have already been conducted on the effects of litter-diversity on litter decomposition (cf. Gartner and Cardon 2004; Hättenschwiler et al. 2005), but investigations covering a broader gradient of deciduous tree species including the
European beech (Fagus sylvatica L.), the predominant tree species in the temperate deciduous forests of Central Europe (e.g., Ellenberg 1996), are relatively scarce. As a consequence of land use history, monospecific stands with beech are abundant in Central Europe. In beech forests, silvicultural management programs attempt to increase the fractions of other broad-leaved tree species such as ash (Fraxinus excelsior L.), lime (Tilia spp.), maple (Acer spp.) and hornbeam (Carpinus betulus L.). However, the effects of elevated tree species diversity on leaf litter decomposition and the ecosystem fluxes of carbon and mineral nutrients are still largely unknown.

To investigate whether leaf litter decomposition in Central European forests is controlled by tree species diversity along a gradient of decreasing fraction of the beech in the tree species composition, we investigated losses of litter-mass and of foliar lignin in site-representative samples and in species-specific litterbags of the component tree species in three stand types: (1) in stands of beech; (2) in stands composed of three main tree species (beech, ash, lime); and (3) in stands comprising five main tree species (beech, ash, lime, hornbeam, maple). All samples were incubated on-site in litterbags. The study was performed in the Hainich region (Thuringia, Central Germany), Germany's largest connected deciduous forest with an area of 16,000 ha. The forest consists of a small mosaic of forest stands dominated by beech on the one hand, and forest stands exceptionally rich in tree species (up to 14 species per hectare) on the other hand.

We hypothesised that (1) the decomposition rates of stand-specific bulk litter increase with decreasing fraction of beech litter due to the increase in leaf litter fractions with a higher quality, and that (2) non-additive effects are responsible for the presumed increase in decomposition rates. We also expected that (3) the decomposition rates of tree species-specific leaf litter increase with decreasing fraction of the beech in the stands due to a higher litter quality in the environment of the incubated litterbags. According to the home field advantage (HFA) hypothesis (Gholz et al. 2000; Vivanco and Austin 2008; Ayres et al. $2009 a, b)$, we tested whether the decomposition rates of beech litter-relative to that of the other tree specieswould be higher in the stands from which it had been derived than in stands with a different tree species composition.

\section{Materials and methods}

Study site

The study was conducted in semi-natural, old-growth forest stands (85-148 years old in 2006; Schmidt et al. 2009) in 
the Hainich National Park, Thuringia, Central Germany. All research stands are situated at an elevation of approximately $350 \mathrm{~m}$ a.s.l. near the village of Weberstedt $\left(51^{\circ} 06^{\prime} \mathrm{N}, 10^{\circ} 31^{\prime} \mathrm{E}\right)$. At the Weberstedt meteorological station, the mean annual temperature is $7.5^{\circ} \mathrm{C}$, and the mean annual precipitation $670 \mathrm{~mm}$. The soils are Luvisols with stagnic properties, which developed from Pleistocene loess and are underlain by limestone (Triassic Upper Muschelkalk formation) (FAO 2006). They are characterised by high silt contents (approximately 75\%), and have a loess cover of at least $60 \mathrm{~cm}$ (Guckland et al. 2009). For the past four decades, the studied stands have developed a nearnatural structure (cf. Mölder et al. 2008; Leuschner et al. 2009). Details of the stand structure are given in Table 1.

In April 2005, three stand types differing in their diversity levels (DL) of tree taxa were selected in the north-eastern part of the national park: (1) a stand type with European beech $(F$. sylvatica $\mathrm{L}$.) as the predominant tree species (DL 1); (2) a stand type mainly consisting of beech, lime (Tilia cordata Mill. and T. platyphyllos Scop.) and ash (F. excelsior L.) (DL 2); and (3) a stand type with beech, lime, ash, hornbeam (Carpinus betulus) and maple (Acer pseudoplatanus L. and Acer platanoides L.) as the predominant tree taxa (DL 3). At each diversity level (stand type), three plots of $50 \mathrm{~m} \times 50 \mathrm{~m}$ each were selected, and fenced to exclude wild boars and other game. All plots were located within a radius of approximately $4 \mathrm{~km}$, and were comparable with respect to slope, physical soil conditions and climate. From the beginning of September, leaf litter was continuously sampled with litter collectors (aperture: $0.29 \mathrm{~m}^{2}$ ) that were arranged at a minimum distance of $2 \mathrm{~m}$ along three randomly positioned 30-m-long transects per plot (five collectors per transect). The bulk of the leaf litter fell from the beginning of October until mid-November. The collectors were emptied every 2-3 weeks from the beginning of September to the end of December during 2005-2007. At all study plots, the air temperature, which can influence the decomposition rates, was continuously recorded with temperature sensors $5 \mathrm{~cm}$ above the ground (HOBO RH/temp H08-32-08; Onset Computer, Bourne, USA). At the measurement dates and the time periods between them, the air temperatures were similar at all plots (data not shown).

\section{Litterbag experiment}

At the beginning of November 2005, $8 \mathrm{~g}$ of oven-dried $\left(25^{\circ} \mathrm{C}\right.$ for $\left.48 \mathrm{~h}\right)$ litter that had been collected in 2005 between the beginning of September and 31 October was placed in nylon bags with a surface area of $20 \mathrm{~cm}^{2}$ and a mesh size of $5 \mathrm{~mm}$. Two types of bags were prepared in this manner: (1) bags that contained litter in a mixture that was representative of the litter composition of the respective plot (MIX bags), and (2) bags that contained litter of only one out of the five investigated tree species (A. platanoides, C. betulus, Fagus sylvatica, Fraxinus excelsior, Tilia cordata; i.e. MONO bags). The MONO-bag litter was derived from a random species-specific mixture from the plots of all DL levels, at which the respective tree species occurred. In part of the remaining litter, the initial concentrations of lignin and calcium $(\mathrm{Ca})$ as well as the initial ratios of carbon to nitrogen ( $\mathrm{C}: \mathrm{N}$ ratios) and carbon to phosphorus (C:P ratios) were determined (see below). On

Table 1 Features of the investigated temperate deciduous forest stands differing in the diversity level (DL) of tree species (means $\pm 1 \mathrm{SE}$, $n=3$, and ranges in the case of soil water content)

\begin{tabular}{|c|c|c|c|}
\hline & DL 1 & DL 2 & DL 3 \\
\hline \multicolumn{4}{|l|}{$\%$ of canopy cover } \\
\hline Fagus sylvatica & $96.1 \pm 1.9 \mathrm{a}$ & $67.1 \pm 3.5 \mathrm{~b}$ & $21.4 \pm 13.0 \mathrm{c}$ \\
\hline Tilia spp. & $0.8 \pm 0.8 \mathrm{~b}$ & $13.1 \pm 5.3 \mathrm{ab}$ & $40.3 \pm 11.0 \mathrm{a}$ \\
\hline Fraxinus excelsior & $0.5 \pm 0.5 \mathrm{a}$ & $14.2 \pm 3.9 \mathrm{a}$ & $10.7 \pm 4.3 \mathrm{a}$ \\
\hline Acer spp. & $0.9 \pm 0.4 \mathrm{~b}$ & $4.5 \pm 1.0 \mathrm{~b}$ & $8.5 \pm 1.3 \mathrm{a}$ \\
\hline Carpinus betulus & $0.0 \pm 0.0 \mathrm{~b}$ & $0.0 \pm 0.0 \mathrm{~b}$ & $14.7 \pm 5.2 \mathrm{a}$ \\
\hline Humus type $^{\mathrm{a}}$ & F-Mull & L-Mull & L-Mull \\
\hline Thickness of organic surface layer, annual average $(\mathrm{cm})^{\mathrm{b}}$ & $2.8 \pm 0.1 \mathrm{a}$ & $2.4 \pm 0.1 \mathrm{~b}$ & $1.9 \pm 0.1 \mathrm{c}$ \\
\hline \multicolumn{4}{|l|}{ Soil water content in $0-10 \mathrm{~cm}$ of soil depth ${ }^{\mathrm{c}}$} \\
\hline Winter 2005/2006 (October-March), range (vol.\%) & $21.0-32.3$ & $19.1-35.4$ & $20.3-34.9$ \\
\hline Summer 2006 (April-September), range (vol \%) & $15.5-34.2$ & $13.9-38.1$ & $13.7-37.4$ \\
\hline
\end{tabular}

Different letters in columns indicate significant differences among DL (data compiled from Guckland et al. 2009 and Jacob et al. 2010)

a According to the German classification system (Ad-hoc-Arbeitsgruppe Boden 2005)

${ }^{\mathrm{b}}$ Unpublished data from N. Weland (Department of Ecology, Johann Friedrich Blumenbach Institute of Zoology and Anthropology, GeorgAugust-Universität Göttingen)

${ }^{c}$ Unpublished data from I. Krämer (Department of Tropical Silviculture and Forest Ecology, Burckhardt-Institute, Georg-August-Universität Göttingen) 
17 November 2005, the litterbags were placed in the upper stratum of the organic surface layer. To cover six sampling dates, six MIX bags were incubated on each plot at all DL (18 bags per DL, 6 sampling dates; 324 bags in total). In the case of the MONO bags, three bags per tree species and plot were placed on one plot at each diversity level to be resampled on three dates ( 3 bags per DL, 5 species, 3 sampling dates; 135 bags in total). For the determination of mass loss on the basis of the remaining litter, litterbags were removed on the following dates: 15 December 2005, 27 March 2006, 19 June 2006, 26 September 2006, 24 April 2007, and 18 September 2007. On these dates (except for sampling dates in 2007 , on which a large part of the litter mass had already decomposed), the lignin concentrations of the remaining material were analysed.

\section{Chemical analyses}

In freshly fallen leaf litter and in part of the litter used for the litterbag experiment, the concentrations of lignin as well as the initial $\mathrm{Ca}$ concentration and the initial $\mathrm{C}: \mathrm{N}$ and C:P ratios were measured. The bulk of the samples was analysed for lignin concentration using near-infrared spectroscopy (NIRS) as a rapid and accurate method for determining lignin in a large number of samples (e.g., Ono et al. 2008). To calibrate the NIRS method, the more time-consuming acetyl bromide method was applied to approximately 100 samples, which had been collected at all DL at all four measurement dates (November 2005-June 2006). In $400 \mathrm{mg}$ of dried $\left(60^{\circ} \mathrm{C}\right)$ and pulverised material per sample, lignin was chemically decomposed into soluble degradation products, whose concentrations were measured photometrically at $280 \mathrm{~nm}$ (Brinkmann et al. 2002). The measurements were calibrated using coniferyl alcohol (1 nmol coniferyl alcohol is equivalent to $180 \mathrm{mg}$ lignin).

For the lignin determination by NIRS, dried and pulverised litter material was homogeneously placed in quartz cuvettes with a diameter of $2 \mathrm{~cm}$. In each sample, the reflectance was measured twice at wavelengths between 400 and 2,500 $\mathrm{nm}$ at 2-nm increments using an NIR spectrometer (Foss NIRSystems 6500, Silver Spring, MD, USA). To minimise the effects of light scattering, the spectra were mathematically transformed to the second derivative (Mclellan et al. 1991; Brinkmann et al. 2002). Calibration was performed using the built-in WinISI software (Foss, Silver Spring, MD, USA) (for technical details, see Tillmann 1996 and Brinkmann et al. 2002). In the samples measured by both methods, the lignin concentrations determined by the acetyl bromide method and by NIRS correlated at an $r^{2}$ of 0.969 .

The $\mathrm{C}$ and $\mathrm{N}$ concentrations of the leaf litter were measured using an automated C:N analyser (Heraeus Elementar
Vario EL, Hanau, Germany). The concentrations of $\mathrm{Ca}$ and $\mathrm{P}$ were determined by ICP-AES (Spectro, Kleve, Germany) after pressure digestion with concentrated nitric acid.

Data evaluation

Decomposition rates $k$ (litter or lignin mass decomposed per gram initial litter mass and per day) were calculated using linear regressions of the mass losses during the first 7 months of decomposition (November 2005 through June 2006; four dates of measurement). As the mass loss during this time period was approximately linear (cf. Fig. 1), we used linear regressions instead of the negative exponential decay that is often used in similar studies (Olson 1963; Bärlocher 2007). Means \pm 1 standard error are given in the

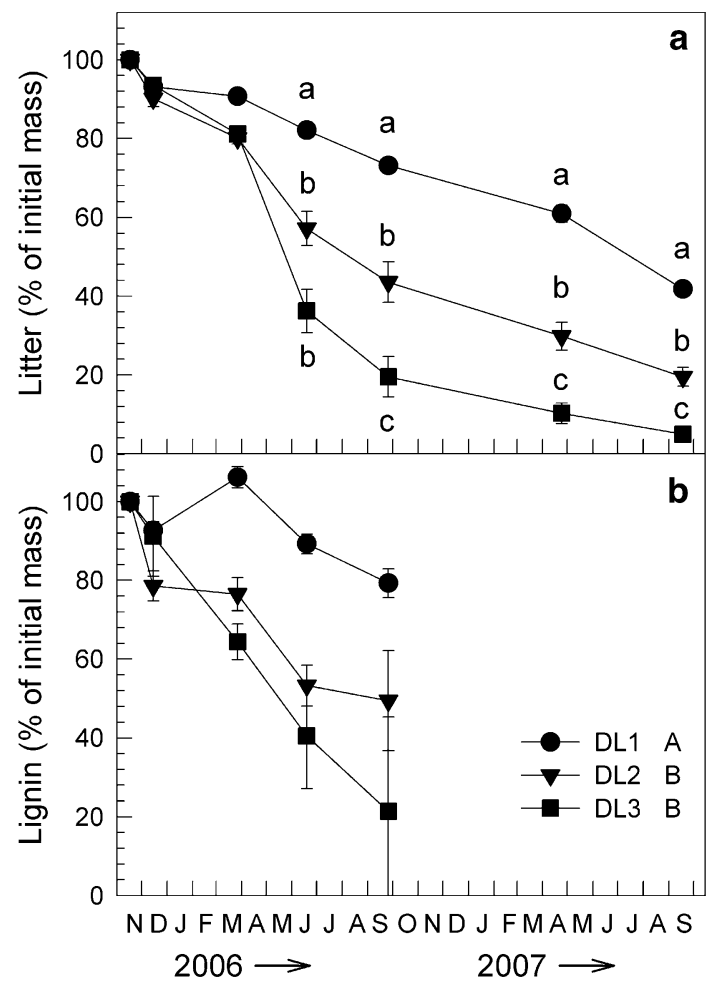

Fig. 1 Decomposition of $\mathbf{a}$ foliar litter and $\mathbf{b}$ foliar lignin in percent of their initial mass in the MIX litterbags (representing the bulk litter of the individual stands) incubated in temperate deciduous forest stands differing in tree species diversity (DL 1-3) from November 2005 until a September 2007 (entire incubation period, 22 months) or b September 2006 (initial 10 months of the incubation) (means $\pm 1 \mathrm{SE}$ ). Different capital letters next to the symbol legends indicate significant differences among DL for the entire time course (Friedman test, followed by multiple pairwise comparisons using the Student-Newman-Keuls test, $P<0.05$; no significant difference among DL for the entire time course in the case of bulk litter). Different lower case letters indicate significant differences among DL on a given date (Kruskal-Wallis test, followed by multiple pairwise $U$ tests; $P<0.05$ ) (the latter test was not performed on the lignin values due to a lack of repetitive analyses on some dates) 
presentation of the results. Differences among the DL within a given tree species, and among the tree species within a given DL, were tested using the Kruskal-Wallis test, followed by multiple pairwise Mann-Whitney rank sum tests ( $U$ tests) in the case of a significant difference. Differences among the time courses of litter or lignin decomposition at the three DL were tested using the Friedman test, followed by multiple pairwise comparisons using the Student Newman-Keuls test in the case of a significant difference. For the decomposition rates in the MONO bags, ANOVA was used for comparing the individual tree species (average values for all DL) or DL (average values for all tree species), followed by post-hoc LSD in the case of significant differences. For each tree species, we tested the differences between predicted (on the basis of MONO litterbags) and measured percentages (in MIX litterbags) of the foliar litter mass remaining after 7 months of incubation using the $t$ test for paired differences after having tested the differences on deviation from the normal distribution using the Kolmogorov-Smirnov test. Interrelationships between the initial $\mathrm{Ca}, \mathrm{N}$ and lignin concentrations in the litter as well as the initial C:N, C:P and lignin: $\mathrm{N}$ ratios as predictor variables, and the litter decomposition rate (November 2005 through June 2006) as the response variable, were tested by multiple regression. For the respective variables, we used values that had been averaged for the individual tree species at each DL $(n=12)$. The tests were performed using SPSS version 13.0.1 (SPSS, Chicago, IL, USA). The significance level was $P<0.05$ in all cases.

For testing the home field advantage (HFA) hypothesis, HFA indices (HFAI) were pairwise calculated according to Ayres et al. (2009b):

$$
\begin{aligned}
\mathrm{HFAI}= & \left(100\left(\mathrm{RML}_{A a}+\mathrm{RML}_{B b}\right)\left(\mathrm{RML}_{A b}+\mathrm{RML}_{B a}\right)^{-1}\right) \\
& -100
\end{aligned}
$$

where RML is the relative mass loss of the litter; capital letters denote the tree species; and lower case letters designate the sites of the tree species. The RML is calculated as the relative mass loss (in percent) of litter of a given tree species (e.g., A) related to the combined relative litter-mass loss of that species (A) and a complementary tree species (B) at a given site (a or b). For pairwise comparisons of tree species, the HFA index gives the percentage of a more rapid (or slower) mass loss of litter when it decomposes under the tree species from which it had been derived (i.e., "at home") than beneath different tree species. In our calculations, the beech stands (DL 1) were site a and the mixed species stands (DL 3), site b. F. sylvatica was species A, and pairwise comparisons were made to A. platanoides, $C$. betulus, $F$. excelsior and T. cordata as the respective $B$ species.

\section{Results}

Litter quality

At all DL, the litter of $F$. sylvatica displayed the highest $\mathrm{C}: \mathrm{N}$ ratios (on average, $53 \mathrm{~g} \mathrm{~g}^{-1}$; significant differences to the other species at DL 2 and DL 3) as well as the highest lignin concentrations (averaged over all DL, $85 \mathrm{mg} \mathrm{g}_{\mathrm{DM}}^{-1}$ ) (Table 2). At DL 2 and DL 3, F. excelsior exhibited the lowest $\mathrm{C}: \mathrm{N}$ ratios (on average of all $\mathrm{DL}, 31 \mathrm{~g} \mathrm{~g}^{-1}$ ). The $\mathrm{Ca}$ concentrations were highest in $T$. cordata (on average of all DL, $25.3 \mathrm{mg} \mathrm{g}_{\mathrm{DM}}^{-1}$ ) and lowest in Fagus (on average, $15.6 \mathrm{mg} \mathrm{g}-1$ DM . Within a given tree species, the differences among DL were not significant for the investigated elements or element ratios.

Table 2 Concentrations of calcium $(\mathrm{Ca})$ and lignin, and ratios of carbon to nitrogen $(\mathrm{C}: \mathrm{N})$ and of carbon to phosphorus $(\mathrm{C}: \mathrm{P})$ in tree litter freshly fallen in autumn in forest stands differing in the level of

\begin{tabular}{|c|c|c|c|}
\hline Tree species & DL 1 & DL 2 & DL 3 \\
\hline \multicolumn{4}{|l|}{$\mathrm{Ca}\left(\mathrm{mg} \mathrm{g}_{\mathrm{DM}}^{-1}\right)$} \\
\hline Fagus sylvatica & $12.5 \pm 1.1$ & $17.8 \pm 0.4 \mathrm{~b}$ & $16.5 \pm 2.9$ \\
\hline Tilia cordata & - & $25.5 \pm 0.4 \mathrm{a}$ & $25.1 \pm 1.1$ \\
\hline Fraxinus excelsior & - & $23.1 \pm 0.8 \mathrm{a}$ & $23.2 \pm 1.0$ \\
\hline Acer platanoides & - & - & $21.4 \pm 0.7$ \\
\hline Carpinus betulus & - & - & $21.8 \pm 1.3$ \\
\hline \multicolumn{4}{|l|}{ Lignin (mg g $\left.g_{D M}^{-1}\right)$} \\
\hline Fagus sylvatica & $80.6 \pm 4.1$ & $86.7 \pm 1.8 \mathrm{a}$ & $88.7 \pm 4.6$ \\
\hline Tilia cordata & - & $71.6 \pm 1.7 \mathrm{~b}$ & $75.7 \pm 2.9$ \\
\hline Fraxinus excelsior & - & $75.8 \pm 1.9 \mathrm{~b}$ & $80.2 \pm 2.4$ \\
\hline Acer platanoides & - & - & $75.8 \pm 1.0$ \\
\hline Carpinus betulus & - & - & $80.7 \pm 3.2$ \\
\hline \multicolumn{4}{|l|}{$\mathrm{C}: \mathrm{N}\left(\mathrm{g} \mathrm{g}^{-1}\right)$} \\
\hline Fagus sylvatica & $50.0 \pm 2.3$ & $52.7 \pm 1.1 \mathrm{a}$ & $57.4 \pm 3.7 \mathrm{a}$ \\
\hline Tilia cordata & - & $35.9 \pm 0.5 \mathrm{~b}$ & $37.0 \pm 1.4 \mathrm{c}$ \\
\hline Fraxinus excelsior & - & $30.1 \pm 1.6 \mathrm{~b}$ & $32.0 \pm 1.1 \mathrm{~d}$ \\
\hline Acer platanoides & - & - & $46.3 \pm 2.3 b$ \\
\hline Carpinus betulus & - & - & $38.6 \pm 2.2 \mathrm{c}$ \\
\hline \multicolumn{4}{|l|}{$\mathrm{C}: \mathrm{P}\left(\mathrm{g} \mathrm{g}^{-1}\right)$} \\
\hline Fagus sylvatica & $543 \pm 47$ & $717 \pm 120$ & $856 \pm 139$ \\
\hline Tilia cordata & - & $446 \pm 34$ & $517 \pm 80$ \\
\hline Fraxinus excelsior & - & $495 \pm 42$ & $532 \pm 44$ \\
\hline Acer platanoides & - & - & $580 \pm 50$ \\
\hline Carpinus betulus & - & - & $508 \pm 48$ \\
\hline
\end{tabular}
tree species diversity (DL) (mean values of 3 replicate plots $\pm 1 \mathrm{SE}$ )

Different letters in columns indicate significant differences among tree species within a given DL (Kruskal-Wallis test, $P<0.05$ ). Differences among DL within a given tree species were not significant 
Decomposition of plot-specific bulk litter across the levels of tree species diversity

Related to their initial values, the quantities of total dry mass and of lignin in the MIX litterbags, which were representative of the bulk litter of the individual study plots, were significantly higher at DL 1 than at DL 2 and DL 3 on the dates of resampling (Fig. 1). During the initial 7 months of the experiment, the rates of litter and lignin decomposition were lowest at DL 1 and highest at DL 3 (Fig. 2).

Decomposition of litter from individual tree species

With regard to the individual tree species (MONO bags), the masses of litter and lignin remaining after the initial 7 months of the experiment (November 2005-June 2006) were highest in Fagus (>80 and $76 \%$, respectively) and lowest in Fraxinus (less than $20 \%$ of the initial litter and lignin) when averaged for all DL (Fig. 3). The decomposition rates $(k)$ of litter and lignin from the individual tree species (MONO bags, mean values for a given DL) did not differ among DL (Fig. 4a, c). This result is in contrast to the significant differences in the $k$ values of the litter mixtures among DL (Fig. 2). Among the individual tree species, $k$ values of litter and lignin (averaged over all DL) did differ significantly: the highest values were found in Fraxinus and the lowest in Fagus (Fig. 4b, d). An additional KruskalWallis test performed separately for tree species and DL revealed that $F$. sylvatica was the only species whose litter (but not lignin) decomposition rates differed among DL: the $k$ value of Fagus litter was significantly higher at DL 1 $\left(0.70 \pm 0.02 \mathrm{mg} \mathrm{g}_{\mathrm{DM}}^{-1} \mathrm{day}^{-1}\right)$ than at DL 2 and DL 3 $\left(0.56 \pm 0.07\right.$ and $\left.0.42 \pm 0.01 \mathrm{mg} \mathrm{g}_{\mathrm{DM}}^{-1} \mathrm{day}^{-1}\right)$.

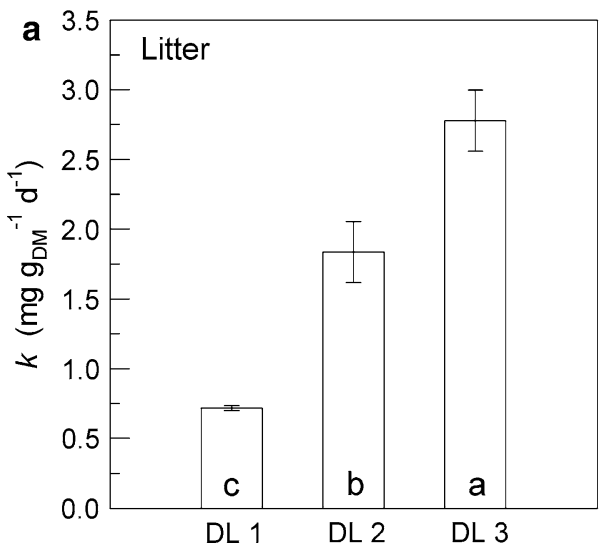

Fig. 2 Decomposition rates ( $k$; related to the initial litter mass) of (a) litter and (b) lignin in stand-specific MIX litterbags incubated in temperate deciduous forest stands differing in their level of tree species diversity (DL 1-3). The rates were calculated for November
To assess the mixture effect on the decomposition, we compared the percentage of the individual tree species' litter remaining in the MIX bags with the percentage predicted on the basis of the MONO bag data after 7 months of decay in accordance with Hättenschwiler and Gasser (2005) (Fig. 5). In Acer and Fagus, the predicted percentage of remaining litter mass in the mixed litterbags tended to be higher than the measured percentage, which indicates a higher rate of decomposition in the mixture, whereas the opposite was true for Tilia. However, the differences between the measured and the predicted percentages were not significant in any of the species.

The HFA index increased with ongoing incubation time for all tree species combinations with the beech (Table 3). The highest HFA index was found for the combination Fagus-Carpinus (20\% higher litter-mass loss at "home" than "away" after 7 months; mean $\pm 1 \mathrm{SE}$ of all four pairwise combinations: $8.1 \pm 4.6 \%$ ). The pairwise comparison of $F$. sylvatica and A. platanoides was the only tree species combination that consistently displayed a more rapid mass loss "away" than "at home".

Relationships between litter quality and decomposition rates

The decomposition rates of the litter were significantly correlated with the initial $\mathrm{N}$ and $\mathrm{Ca}$ concentrations in the litter as well as with the initial $\mathrm{C}: \mathrm{N}, \mathrm{C}: \mathrm{P}$ and lignin: $\mathrm{N}$ ratios (Fig. 6). The initial lignin concentration was not significantly related to the decomposition rate. Multiple regression yielded its highest adjusted coefficient of determination $\left(R_{\text {adj }}^{2}\right)$ with the $\mathrm{N}$ concentration, the C:P ratio and the $\mathrm{C}: \mathrm{N}$ ratio as predictor variables. However, with these predictor variables, the explanatory power was only slightly higher

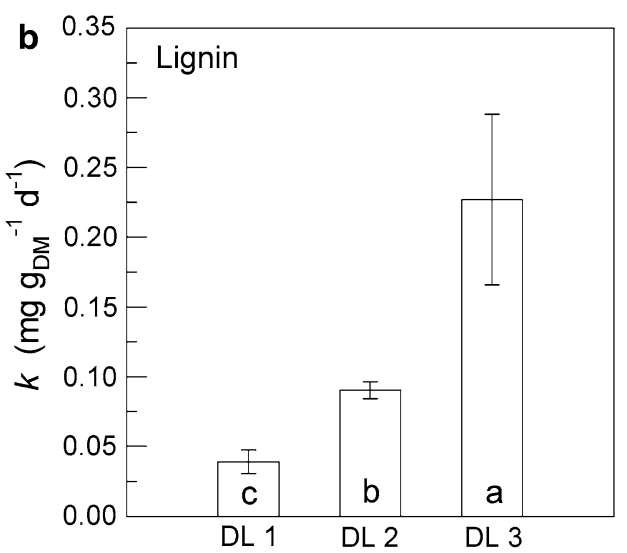

2005-June 2006 (means \pm 1 SE). Different lower case letters indicate significant differences among DL (Kruskal-Wallis test, followed by multiple pairwise $U$ tests; $P<0.05$ ) 


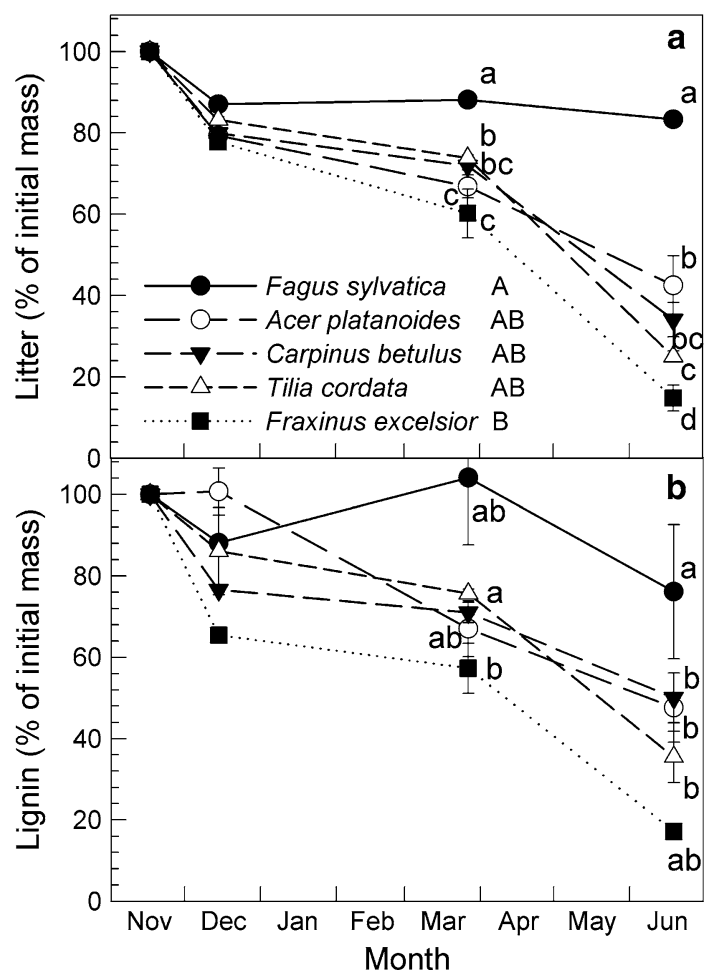

Fig. 3 Decomposition of (a) foliar litter and (b) foliar lignin of different temperate deciduous forest tree species in percent of their initial mass in MONO litterbags (average values of bags incubated in stands of the three tree species diversity levels DL 1-3) (means $\pm 1 \mathrm{SE}$ ). Different capital letters next to the symbol legends indicate significant differences among tree species for the entire time course (Friedman test, followed by multiple pairwise comparisons using the Student Newman-Keuls test; $P<0.05)$ in the case of litter decomposition (no significant differences in the case of lignin decomposition). Different lower case letters indicate significant differences among tree species on a given date (Kruskal-Wallis test, followed by multiple pairwise $U$ tests; $P<0.05$ )

than that of a simple regression with $\mathrm{C}: \mathrm{N}$ as the sole predictor variable (Table 4). Inclusion of further variables resulted in lower $R_{\text {adj }}^{2}$ values, probably because of variance inflation due to multicollinearity among the variables.

\section{Discussion}

The species-specific litter decomposition rates varied among the investigated tree species but, in most species, were neither influenced by litter mixing (i.e., by raising the litter diversity) nor by the degree of the tree species diversity at the sites of decomposition. However, the decomposition rates of stand-specific bulk litter increased with decreasing portion of the beech in the tree species composition and, thus, with increasing tree species diversity. With ongoing incubation time (up to 7 months), an increase in home field advantage was found for litter decomposition in all pairwise combinations of Fagus with other tree species except for A. platanoides.

Decomposition of litter from individual tree species

Our findings of significant correlations between initial litter decomposition rates and $\mathrm{N}$-related variables of the litter corroborate the results of other studies, which demonstrated that the $\mathrm{N}$ concentrations, or the ratios of $\mathrm{N}$ to other foliar compounds, are among the principal factors affecting the rates of litter decomposition in a particular climatic region (Cornelissen 1996; Aerts 1997; Heal et al. 1997; Parton et al. 2007). Like in our study, a significantly positive correlation has also been found between the decomposition rates and the $\mathrm{Ca}$ concentration of the litter (Hobbie et al. 2006). However, it has to be considered that (1) correlations between nutrient concentrations and litter decomposition rates do not necessarily imply that litter quality controls litter decay, and (2) simple extrapolations of decomposition rates from early stages of decay to longterm rates might yield erroneous results (Prescott 2005).

The lack of a significant correlation between decomposition rates and the lignin concentration of the litter was probably due to the relatively small range of lignin concentrations. Moreover, lignin's regulation of litter decomposition is generally not presumed to take effect before the onset of the second phase of degradation (Kalbitz et al. 2006; Berg and McClaugherty 2008), which starts when the mass loss of litter exceeds a species-specific level. This level might not have been reached during the period for which the decomposition rates were calculated.

Due to the chemical composition of their leaves, forest trees create specific conditions that influence the decomposition of their own litter in the long-term (Reich et al. 2005; Sariyildiz and Anderson 2005; Vivanco and Austin 2008). Apart from affecting the chemical composition of the soil, litter that is only slowly degradable builds up thicker layers of organic matter on the soil surface, which persist over longer periods of time. The structure of the organic surface layer, in turn, can affect the rates of litter decomposition as a result of the microclimatic conditions (Sayer 2006; Sariyildiz 2008). In our study, the thicker organic surface layer in the stands dominated by $F$. sylvatica (DL 1) might have preserved a more favourable moisture regime during the decomposition process than at DL 2 and DL 3. At the latter DL (especially at DL 3), the more rapid decomposition of the readily degradable Fraxinus and Tilia litter, which presumably is a more attractive resource to the decomposers due to its lower $\mathrm{C}: \mathrm{N}$ ratios, left behind a thinner litter layer. In late spring ( 7 months after the onset of decomposition), this layer consisted mainly of the more persistent Fagus litter, whose decomposition might have been further retarded by the low moisture 
Fig. 4 Decomposition rates $(k$; related to the initial litter mass) of litter $(\mathbf{a}, \mathbf{b})$ and lignin $(\mathbf{c}, \mathbf{d})$ in tree species-specific MONO litterbags incubated in temperate deciduous forest stands differing in their level of tree species diversity (DL 1-3).

The rates were calculated for November 2005-June 2006 (means $\pm 1 \mathrm{SE}$ ). The means were averaged for a given DL from the litter of all tree species incubated there (A. platanoides, $C$. betulus, $F$. sylvatica, $F$. excelsior, T. cordata) (a,c), or over all DL (DL 1-3) for a given tree species $(\mathbf{b}, \mathbf{d})$.

Different lower case letters indicate significant differences among the tree species

(ANOVA, followed by post-hoc LSD tests; $P<0.05$ ).

Differences among DL were not significant

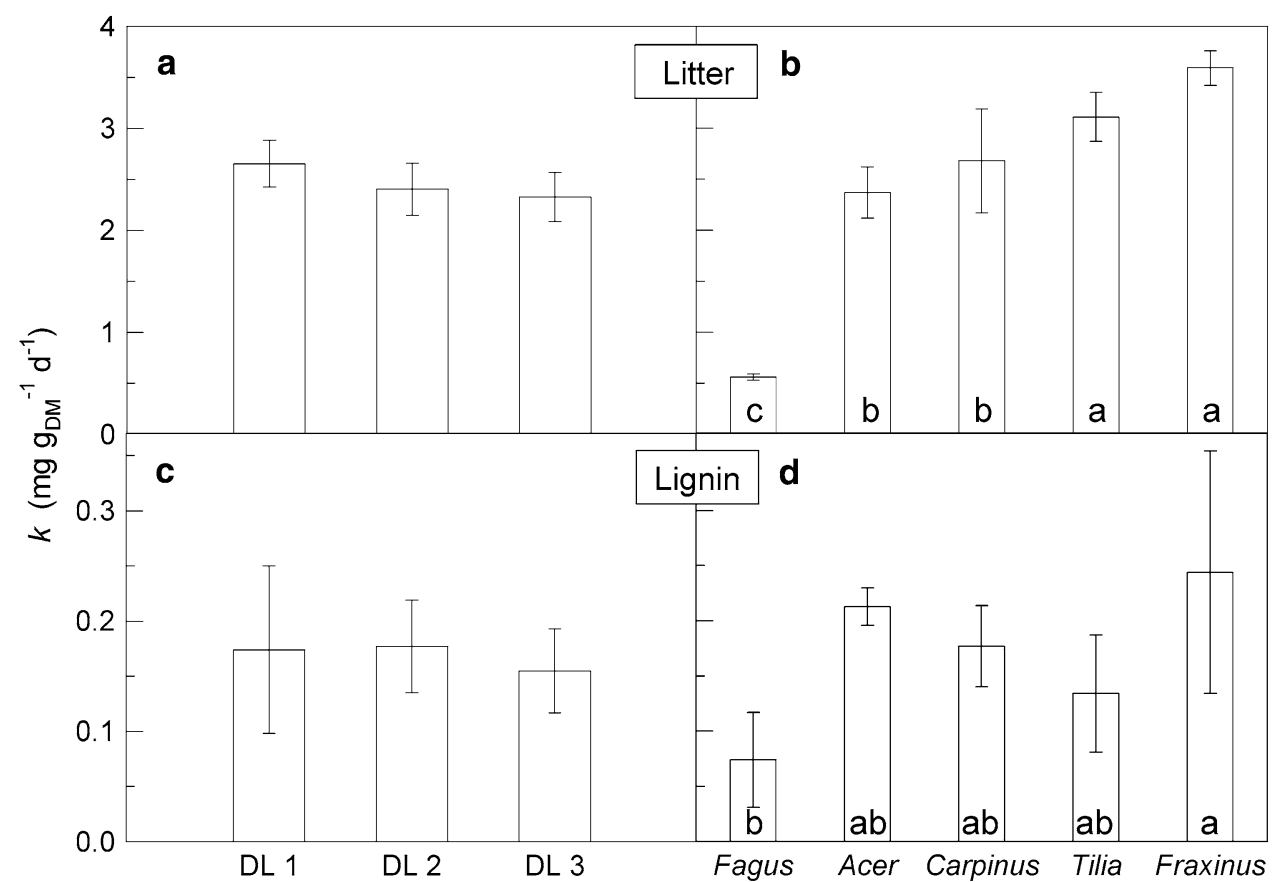

content during the warm summer months. In the multispecific stands, this might have impeded the degradation of Fagus litter even more. The moisture regime in the litter layer and decomposer preferences might explain the finding that the decomposition rates of Fagus litter at DL 2 and DL 3 during the first 7 months of decay were significantly lower than in the almost pure Fagus stands of DL 1. The combination of these factors might also have been involved in the home field advantage (HFA) found after 7 months of litter decomposition in pairwise comparisons of $F$. sylvatica to the other investigated tree species (except for A. platanoides), which was evident by positive HFA indices. The mean value of the HFA indices calculated in our study after 7 months (8.1\%) was almost identical to the value of $8.0 \%$ found by Ayres et al. (2009b) in a meta-analysis of 35 pairwise forest tree comparisons (incubation time 0.75 years) conducted in North and South America and Europe. A local adaptation of the soil community of microorganisms and fauna to the stand-specific litter, which is also presumed to cause HFA (e.g., Ayres et al. 2009a, b), might have been involved as well. It has to be noted, however, that-in contrast to the initial trend-the decomposition of Fagus litter was more rapid at DL 3 than at DL 1 when a longer time period ( 22 months) of decomposition was considered (Jacob et al. 2009). The HFA hypothesis should be more thoroughly tested for longer time spans in temperate forests that are rich in tree species by nature and also harbour monospecific stands consisting of different tree species-in contrast to Central European deciduous forests that are largely dominated by one single species ( $F$. sylvatica), which also is one of the very few species that forms appreciable monospecific stands.

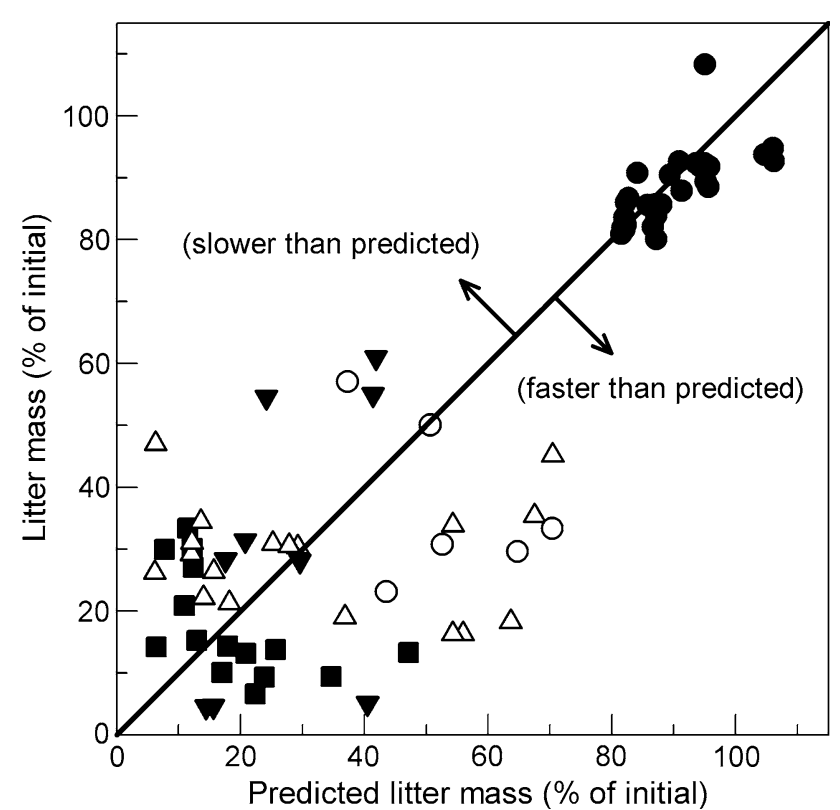

Fig. 5 Predicted (on the basis of MONO litterbags) and measured percentages (in MIX litterbags) of the different tree species' foliar litter remaining after 7 months of incubation in all DL (DL 1-3). The diagonal line represents a 1:1 ratio. Within a given tree species, the differences between measured and predicted differences were not significant ( $t$ test for paired differences). For the explanation of symbols, see Fig. 3

\section{Decomposition of litter mixtures}

The investigated mixed forest stands showed, in their initial phase, an additive litter decomposition, which can be predicted by the mass loss of the component litter species. We 
Table 3 Indices of home field advantage (HFA) calculated for pairwise comparisons of decomposition of beech litter $(F$. sylvatica) to the decomposition of litter from Acer platanoides, $C$. betulus, F. excelsior and T. cordata according to Ayres et al. (2009b)

\begin{tabular}{llcc}
\hline & \multicolumn{3}{l}{ HFA index } \\
\cline { 2 - 4 } & 1 month & 4 months & 7 months \\
\hline Fagus-Acer & -3.6 & -3.3 & -2.3 \\
Fagus-Carpinus & -3.3 & 3.6 & 20.0 \\
Fagus-Fraxinus & -5.9 & -10.2 & 5.9 \\
Fagus-Tilia & 4.0 & 3.4 & 8.7 \\
\hline
\end{tabular}

The HFA indices are based on litter-mass loss determined after 1, 4 and 7 months of litter decomposition in MONO bags $(n=3)$ incubated in the monospecific stands (pure beech stands; DL 1), and in the multispecific stands of DL 3. They give the percentage of a more rapid (positive sign) or a slower (negative sign) mass loss of litter when it decomposes at "home" (the stand type from which the litter had been derived) versus "away" (a stand type with a different tree species composition)

cannot support the widespread hypothesis that litter decomposition is more rapid in the presence of more readily degradable leaf litter. This result contrasts those of a substantial number of studies, which have shown that mass loss from foliar litter of a given species is enhanced when foliar litter of other species is present (cf. Gartner and Cardon 2004). However, only a few studies have investigated the decomposition of the same litter types across sites differing in the composition of litter species. In several of those studies (in boreal forests, Prescott et al. 2000; in a temperate forest, Ball et al. 2008; in dry-mesic to mesic forests of Central North America, Madritch and Cardinale 2007; and in a Nothofagus mixed forest in Patagonia, Vivanco and Austin 2008), no enhancing effects of speciesrich environments on the mass loss of individual litter species were detected. Instead, individual leaf litter quality seemed to be crucial for the decomposition rates, at least in the initial phase of decay. This conclusion can also be drawn from the present study. It provides further evidence that the properties of individual litter species are decisive for their decomposition rates.

\section{Decomposition across the DL}

According to our hypothesis, the large differences between the decomposition rates of beech litter and those of litter from the other investigated tree species also influenced the decomposition rates of the stand-specific litter mixtures, which were highest at DL 3. In those stands with the highest tree species diversity, tree species with low initial $\mathrm{C}: \mathrm{N}$ ratios in their litter ( $C$. betulus, F. excelsior, Tilia cordata) together made up nearly twothirds of the canopy cover, whereas the species with the highest $\mathrm{C}: \mathrm{N}$ ratio ( $F$. sylvatica) contributed only about
$21 \%$. The stand-specific litter mixtures reflected the contribution of the tree species to the canopy cover. Despite distinct differences among DL in soil chemistry (Guckland et al. 2009), the nutrient concentrations and ratios of Fagus litter did not differ significantly among DL. Thus, high fractions of $F$. sylvatica in the litter mixtures were connected with lower decomposition rates of total litter and lignin. Hence, in our study, the differences among the decomposition rates of the litter mixtures from the various DL were due to the specific traits of the individual tree species involved, and to their interrelations with the site factors rather than to the diversity of the litter mixtures per se. Generally, the strongly varying effects (some are stimulating, others are retarding) of species-specific traits of the trees in temperate forest ecosystems make the prediction of littermixing effects on the decomposition rates difficult (Hättenschwiler et al. 2005; De Deyn et al. 2008). This also seems to be true for tropical forest plantations (Scherer-Lorenzen et al. 2007).

\section{Consequences of leaf litter decomposition} at the ecosystem scale

The annual leaf litter production of the investigated stands was $3.2-3.9 \mathrm{Mg} \mathrm{ha}^{-1}$ year $^{-1}$, with no significant differences among the levels of tree species diversity (Guckland et al. 2009). The higher decomposition rates in the stands with a lower portion of the beech in the tree species composition and with a higher tree species diversity is indicative of a faster release of nutrients and, thus, of a more rapid nutrient cycling. Given the different chemical composition of the investigated litter species, it is probable that the cycling of $\mathrm{C}$ and $\mathrm{N}$ during decomposition is influenced by the chemical composition of the litter mixtures rather than by features of diversity. Meier and Bowman (2008) also drew such a conclusion from their study on the decomposition of litter mixtures from alpine plant species. However, if such alterations in the $\mathrm{C}$ and $\mathrm{N}$ cycling have occurred along the gradient of a decreasing fraction of the beech at our study sites, they exerted no influence on the productivity of the trees: the basal area-related productivity of the beech was not higher in the mixed stands than in the pure ones, and the stand-related total above-ground productivity of all trees even tended to decrease with increasing tree species diversity (Jacob et al. 2010). Hence, the total aboveground productivity of the trees seems to be unaffected by the litter decomposition rates. This is consistent with the objection by Prescott (2005) that rates of litter decomposition may not be critical for productivity although the process of litter decomposition is crucial to maintain production. With regard to the rates of litter 
Fig. 6 Rates of litter decomposition $(k)$ plotted against the initial concentrations or ratios of nutrients or lignin in the litter from tree speciesspecific MONO litterbags incubated in temperate deciduous forest stands differing in the level of tree species diversity. Mean values of the DL were used for each tree species. The decomposition rates were calculated for November 2005-June 2006. In cases of significant $(P<0.05)$ Pearson correlation coefficients $(r), r$ and the respective levels of significance are given. For the explanation of symbols, see Fig. 3
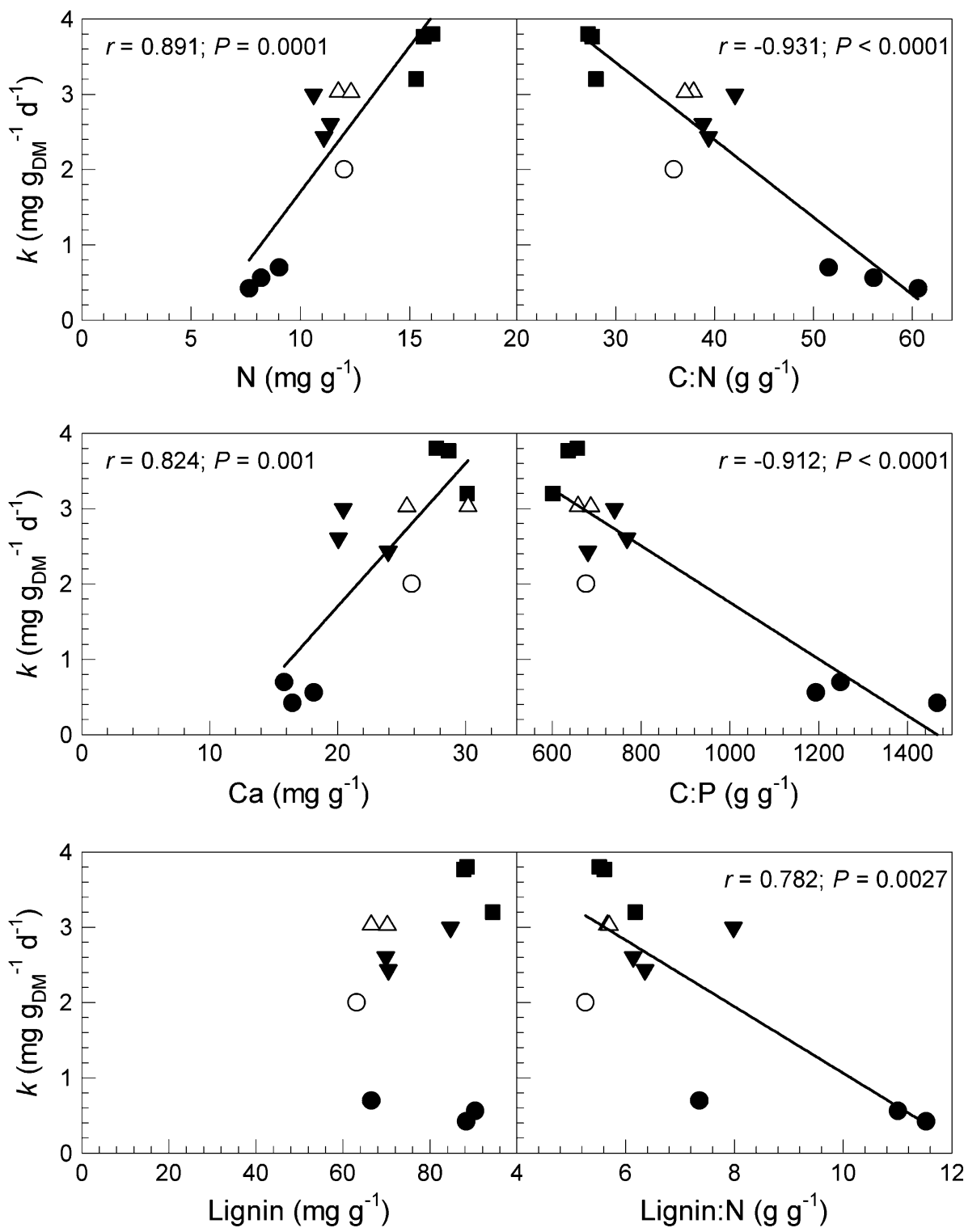

Table 4 Significant coefficients of determination $\left(R^{2}\right.$ and adjusted $R^{2}$ ) resulting from multiple regression analysis on the influence of the initial concentrations and ratios of several chemical compounds of the leaf litter from different deciduous forest tree species (A. platanoides, $C$. betulus, F. sylvatica, F. excelsior, T. cordata) on the decomposition rate (response variable) during the initial 7 months of decomposition (November 2005-June 2006)

\begin{tabular}{llll}
\hline Predictor variables & $R^{2}$ & $R_{\text {adj }}^{2}$ & \multicolumn{1}{l}{$P$} \\
\hline C:N & 0.867 & 0.853 & $<0.001$ \\
C:P, N & 0.900 & 0.877 & $<0.001$ \\
C:N, C:P, N & 0.911 & 0.878 & $<0.001$ \\
C:N, C:P, N, Ca & 0.922 & 0.877 & $<0.001$ \\
C:N, C:P, N, Ca, lignin:N & 0.927 & 0.867 & 0.002 \\
C:N, C:P, N, Ca, lignin:N, lignin & 0.929 & 0.844 & 0.010
\end{tabular}

The analysis was performed on average values of the individual tree species (MONO litterbags) at the different DL $(n=12)$ decomposition and nutrient release, however, the site conditions of the different stand types, in combination with the specific traits of the predominating tree species, might be more important than tree species diversity itself.

Acknowledgments We thank Nadine Weland (Dept. of Ecology, Johann Friedrich Blumenbach Institute of Zoology and Anthropology, Georg-August-Universität Göttingen) for providing data on the thickness of the organic surface layer; and Inga Krämer (Dept. of Tropical Silviculture and Forest Ecology, Burckhardt Institute, Georg-August-Universität Göttingen) for providing data on the soil water content. The helpful comments of two anonymous reviewers and of the Handling Editor (Stephan Hättenschwiler) are greatly acknowledged. The study was funded by the Deutsche Forschungsgemeinschaft (Graduiertenkolleg 1086). The experiments comply with the laws of Germany where they have been conducted.

Open Access This article is distributed under the terms of the Creative Commons Attribution Noncommercial License which 
permits any noncommercial use, distribution, and reproduction in any medium, provided the original author(s) and source are credited.

\section{References}

Ad-hoc-Arbeitsgruppe Boden (2005) Bodenkundliche Kartieranleitung. Schweizerbart'sche Verlagsbuchhandlung, Stuttgart

Aerts R (1997) Climate, leaf litter chemistry and leaf litter decomposition in terrestrial ecosystems: a triangular relationship. Oikos 79:439-449

Ayres E, Steltzer H, Berg S, Wall DH (2009a) Soil biota accelerate decomposition in high-elevation forests by specializing in the breakdown of litter produced by the plant species above them. J Ecol 97:901-912

Ayres E, Steltzer H, Simmons BL, Simpson RT, Steinweg JM, Wallenstein MD, Mellor N, Parton WJ, Moore JC, Wall DH (2009b) Home-field advantage accelerates leaf litter decomposition in forests. Soil Biol Biochem 41:606-610

Ball BA, Hunter MD, Kominoski JS, Swan CM, Bradford MA (2008) Consequences of non-random species loss for decomposition dynamics: experimental evidence for additive and non-additive effects. J Ecol 96:303-313

Balvanera P, Pfisterer AB, Buchmann N, He JS, Nakashizuka T, Raffaelli D, Schmid B (2006) Quantifying the evidence for biodiversity effects on ecosystem functioning and services. Ecol Lett 9:1146-1156

Bärlocher F (2007) Leaf mass loss estimated by litter bag technique. In: Graça MAS, Bärlocher F, Gessner MO (eds) Methods to study litter decomposition-a practical guide. Springer, Dordrecht, pp 37-42

Berg B, McClaugherty C (2008) Plant litter-decomposition, humus formation, carbon sequestration. Springer, Berlin

Brinkmann K, Blaschke L, Polle A (2002) Comparison of different methods for lignin determination as a basis for calibration of near-infrared reflectance spectroscopy and implications of lignoproteins. J Chem Ecol 28:2483-2501

Chapman SK, Koch GW (2007) What type of diversity yields synergy during mixed litter decomposition in a natural forest ecosystem? Plant Soil 299:153-162

Cornelissen JHC (1996) An experimental comparison of leaf decomposition rates in a wide range of temperate plant species and types. J Ecol 84:573-582

Cotrufo MF, Miller M, Zeller B (2000) Litter decomposition. In: Schulze E-D (ed) Carbon and nitrogen cycling in European forest ecosystems. Ecological studies 142. Springer, Berlin, pp 276-296

De Deyn GB, Cornelissen JHC, Bardgett RD (2008) Plant functional traits and soil carbon sequestration in contrasting biomes. Ecol Lett 11:516-531

Ellenberg H (1996) Vegetation Mitteleuropas mit den Alpen. Ulmer, Stuttgart

FAO (2006) FAO, ISRIC, ISSS World Reference Base for Soil Resources 2006. Report No. 103. World Soil Resources Reports, Rome

Gartner TB, Cardon ZG (2004) Decomposition dynamics in mixedspecies leaf litter. Oikos 104:230-246

Gholz HL, Wedin DA, Smitherman SM, Harmon ME, Parton WJ (2000) Long-term dynamics of pine and hardwood litter in contrasting environments: toward a global model of decomposition. Global Change Biol 6:751-765

Guckland A, Jacob M, Flessa H, Thomas FM, Leuschner C (2009) Acidity, nutrient stocks, and organic-matter content in soils of a temperate deciduous forest with different abundance of
European beech (Fagus sylvatica L.). J Plant Nutr Soil Sci 172:500-511

Hättenschwiler S, Gasser P (2005) Soil animals alter plant litter diversity effects on decomposition. Proc Natl Acad Sci USA 102:1519-1524

Hättenschwiler S, Tiunov AV, Scheu S (2005) Biodiversity and litter decomposition in terrestrial ecosystems. Annu Rev Ecol Evol Syst 36:191-218

Heal OW, Anderson JM, Swift MJ (1997) Plant litter quality and decomposition: an historical overview. In: Cadisch G, Giller KE (eds) Driven by nature: plant litter quality and decomposition. CAB International, Wallingford, pp 3-30

Hobbie SE, Reich PB, Oleksyn J, Ogdahl M, Zytkowiak R, Hale C, Karolewski P (2006) Tree species effects on decomposition and forest floor dynamics in a common garden. Ecology 87:2288-2297

Hooper DU, Chapin FS III, Ewel JJ, Hector A, Inchausti P, Lavorel S, Lawton JH, Lodge DM, Loreau M, Naeem S, Schmid B, Setälä H, Symstad AJ, Vandermeer J, Wardle DA (2005) Effects of biodiversity on ecosystem functioning: a consensus of current knowledge. Ecol Monogr 75:3-35

Jacob M, Weland N, Platner C, Schaefer M, Leuschner C, Thomas FM (2009) Nutrient release from decomposing leaf litter of temperate deciduous forest trees along a gradient of increasing tree species diversity. Soil Biol Biochem 41:2122-2130

Jacob M, Leuschner C, Thomas FM (2010) Productivity of temperate broad-leaved forest stands differing in tree species diversity. Ann For Sci 67:503p1-503p9

Kalbitz K, Kaiser K, Bargholz J, Dardenne P (2006) Lignin degradation controls the production of dissolved organic matter in decomposing foliar litter. Eur J Soil Sci 57:504-516

Leuschner C, Jungkunst H, Fleck S (2009) Functional role of forest diversity: pros and cons of synthetic stands and across-site comparisons in established forests. Basic Appl Ecol 10:1-9

Madritch MD, Cardinale BJ (2007) Impacts of tree species diversity on litter decomposition in northern temperate forests of Wisconsin, USA: a multi-site experiment along a latitudinal gradient. Plant Soil 292:147-159

Mclellan TM, Aber JD, Martin ME, Melillo JM, Nadelhoffer KJ (1991) Determination of nitrogen, lignin, and cellulose content of decomposing leaf material by near-infrared reflectance spectroscopy. Can J For Res 21:1684-1688

Meier CL, Bowman WD (2008) Links between plant litter chemistry, species diversity, and below-ground ecosystem function. Proc Natl Acad Sci USA 105:19780-19785

Melillo JM, Aber JD, Muratore JF (1982) Nitrogen and lignin control of hardwood leaf litter decomposition dynamics. Ecology 63:621-626

Mölder A, Bernhardt-Römermann M, Schmidt W (2008) Herb-layer diversity in deciduous forests: raised by tree richness or beaten by beech? For Ecol Manage 256:272-281

Olson JS (1963) Energy storage and balance of producers and decomposers in ecological systems. Ecology 44:322-331

Ono K, Miki K, Amari M, Hirai K (2008) Near-infrared reflectance spectroscopy for the determination of lignin-derived compounds in the decomposed and humified litters of coniferous and deciduous temperate forests in Northern Kanto District, Central Japan. Soil Sci Plant Nutr 54:188-196

Osono T (2007) Ecology of ligninolytic fungi associated with leaf litter decomposition. Ecol Res 22:955-974

Osono T, Takeda H (2005) Decomposition of organic chemical components in relation to nitrogen dynamics in leaf litter of 14 tree species in a cool temperate forest. Ecol Res 20:41-49

Parton W, Silver WL, Burke IC, Grassens L, Harmon ME, Currie WS, King JY, Adair EC, Brandt LA, Hart SC, Fasth B (2007) Globalscale similarities in nitrogen release patterns during long-term decomposition. Science 315:361-364 
Pérez Harguindeguy N, Blundo CM, Gurvich DE, Díaz S, Cuevas E (2008) More than the sum of its parts? Assessing litter heterogeneity effects on the decomposition of litter mixtures through leaf chemistry. Plant Soil 303:151-159

Prescott CE (2005) Do rates of litter decomposition tell us anything we really need to know? For Ecol Manage 220:66-74

Prescott CE, Zabek LM, Staley CL, Kabzems R (2000) Decomposition of broadleaf and needle litter in forests of British Columbia: influences of litter type, forest type, and litter mixtures. Can J For Res 30:1742-1750

Reich PB, Oleksyn J, Modrzynski J, Mrozinski P, Hobbie SE, Eissenstat DM, Chorover J, Chadwick OA, Hale CM, Tjoelker MG (2005) Linking litter calcium, earthworms and soil properties: a common garden test with 14 tree species. Ecol Lett 8:811818

Salamanca EF, Kaneko N, Katagiri S (1998) Effects of leaf litter mixtures on the decomposition of Quercus serrata and Pinus densiflora using field and laboratory microcosm methods. Ecol Eng 10:53-73

Sariyildiz T (2008) Effects of gap-size classes on long-term litter decomposition rates of beech, oak and chestnut species at high elevations in Northeast Turkey. Ecosystems 11:841-853

Sariyildiz T, Anderson JM (2005) Variation in the chemical composition of green leaves and leaf litters from three deciduous tree species growing on different soil types. For Ecol Manage 210:303-319

Sayer EJ (2006) Using experimental manipulation to assess the roles of leaf litter in the functioning of forest ecosystems. Biol Rev 81:1-31

Scherer-Lorenzen M, Potvin C, Koricheva J, Schmid B, Hector A, Bornik Z, Reynolds G, Schulze E-D (2005) The design of experimental tree plantations for functional biodiversity research. In: Scherer-Lorenzen M, Körner C, Schulze E-D (eds) Forest diversity and function. Ecological studies 176. Springer, Berlin, pp 347-376
Scherer-Lorenzen M, Bonilla JL, Potvin C (2007) Tree species richness affects litter production and decomposition rates in a tropical biodiversity experiment. Oikos 116:2108-2124

Schimel JP, Cates RG, Ruess R (1998) The role of balsam poplar secondary chemicals in controlling soil nutrient dynamics through succession in the Alaskan taiga. Biogeochemistry 42:221-234

Schmidt I, Leuschner C, Mölder A, Schmidt W (2009) Structure and composition of the seed bank in monospecific and tree speciesrich temperate broad-leaved forests. For Ecol Manage 257:695702

Spehn EM, Hector A, Joshi J, Scherer-Lorenzen M, Schmid B, Bazeley-White E, Beierkuhnlein C, Caldeira MC, Diemer M, Dimitrakopoulos PG, Finn JA, Freitas H, Giller PS, Good J, Harris R, Högberg P, Huss-Danell K, Jumpponen A, Koricheva J, Leadley PW, Loreau M, Minns A, Mulder CPH, O'Donovan G, Otway SJ, Palmborg C, Pereira JS, Pfisterer AB, Prinz A, Read DJ, Schulze E-D, Siamantziouras ASD, Terry AC, Troumbis AY, Woodward FI, Yachi S, Lawton JH (2005) Ecosystem effects of biodiversity manipulations in European grasslands. Ecol Monogr 75:37-63

Tillmann P (1996) Kalibrationsentwicklung für NIRS-Geräte-eine Einführung. Cuvillier, Göttingen

Vivanco L, Austin AT (2008) Tree species identity alters forest litter decomposition through long-term plant and soil interactions in Patagonia, Argentina. J Ecol 96:727-736

Wardle DA, Bonner KI, Nicholson KS (1997) Biodiversity and plant litter: experimental evidence which does not support the view that enhanced species richness improves ecosystem function. Oikos 79:247-258

Wardle DA, Bardgett RD, Walker LR, Bonner KI (2009) Among- and within-species variation in plant litter decomposition in contrasting long-term chronosequences. Funct Ecol 23:442-453 